\title{
Morphosyntactic features of the indefinite tot in old Romanian
}

\author{
Isabela Nedelcu* \\ Faculty of Letters, University of Bucharest, 5-7 Edgar Quinet St., 010017 Bucharest, Romania \\ "Iorgu Iordan - Al. Rosetti" Institute of Linguistics, 13 Calea 13 Septembrie, 050711 Bucharest, Romania
}

\section{Article info}

History:

Received May 26, 2017

Accepted June 3, 2017

Published September 30, 2017

Key words:

indefinite pronoun

indefinite adjective

quantifier

old Romanian

variation

\begin{abstract}
This article establishes and discusses a series of morphosyntactic features of the indefinite tot 'whole, all' in old Romanian, relating them to modern Romanian: forms that disappeared from the language, a wider variety of singular and plural genitive-dative markers (synthetic, analytic and mixed), the more permissive word order and the possibility to occur in a structure with an undetermined noun. The description of the grammatical characteristics of the quantifier tot highlights a great variation: (i) between the synthetic, analytic and mixed realization of the genitive-dative case (toatei all.F.SG.GEN $\equiv$ DAT 'of/to the whole' + genitive-dative noun, a/la/de toată A/LA/DE all.F.SG.NOM $\equiv \mathrm{ACC}$ 'of/to the whole' + nominative-accusative noun, a toată A all.F.SG.NOM $\equiv$ ACC 'of/to the whole' + genitive-dative noun); (ii) between the (pronominal and adjectival) form with the final particle $-a$ and the one without $-a$ (tuturor, tuturora 'of all / to all'; tuturor oamenilor 'of/to all the people', tuturora fraților 'of/to all the brothers'); (iii) between the postposition and anteposition of tot relative to certain pronouns (ei toți, toți ei 'all of them'); (iv) between structures with a determined and an undetermined noun (toate zilele, toate zile 'all the days'). The comparison with the modern language shows that, in some cases, this variation has been eliminated, and in other cases, it is preserved.
\end{abstract}

\section{Introduction}

In old Romanian (the $16^{\text {th }}$ to $18^{\text {th }}$ century), the indefinite pronoun and pronominal adjective tot 'whole, all', with the function of universal quantifier, has a series of morphological and syntactic characteristics, of which the most important ones will be discussed in this study.

The contexts extracted from the old Romanian corpus illustrate the globalizing value of the universal quantifier tot (1a), as well as its distributive value, which occurs when the structure contains a singular noun with generic use, synonymous with fiecare 'each' (1b) (see Giurgea, 2013, p. 169; Stan, 2016b, p. 352 for the value of distributive universal quantifier of tot in prenominal position).

(1) a. cistitul honourable.M.SG.DEF

$$
\text { împărat }
$$$$
\text { emperor.NOM }
$$

şi cu toată țara

and with

all.F.SG

$$
\text { coun }
$$
domnii

$\mathrm{cu}$ toț

with all.M.PL

îmbla şi a walk.INF and $A_{\text {INF }}$ să mă

S. $\breve{A U B J}_{\text {SUJ }} \quad$ CL.ACC.1SG ransom.SUBJ.3PL și cu tot all.M.sG

svatul should see to my need, all of them should buy my freedom'

\footnotetext{
*Email address: isabela.nedelcu@yahoo.com.
} 
b. tot creștinul, oare păcătos, oare dirept, are

each.M.sG Christian.DEF.NOM or sinner or right has

cineș ingerul său socotitoriu (CazV.1643, 22 $\left.{ }^{\mathrm{r}}\right)$

each.NOM angel.DEF.ACC his.POss judging(ADJ)

'all the Christians, be they sinners or righteous men, have their angel judging them'

\section{Morphological characteristics of the pronoun and pronominal adjective tot}

Just like in modern Romanian, the indefinite tot has different gender and number forms: tot M.SG, toată F.SG, toți M.PL, toate F.PL. The-partial-differences with modern Romanian arise in the marking of oblique cases, only in the singular, because the plural genitive-dative form does not undergo changes in the two periods of the language: tuturor (a). While in modern Romanian tot does not mark the genitivedative inflectionally, in old Romanian, when used as an adjective, it has the feminine form toatei (2a-e), attested, at the end of the $17^{\text {th }}$ and the beginning of the $18^{\text {th }}$ century (Pană Dindelegan, 2013, p. 166167), in original and translated texts ${ }^{1}$.

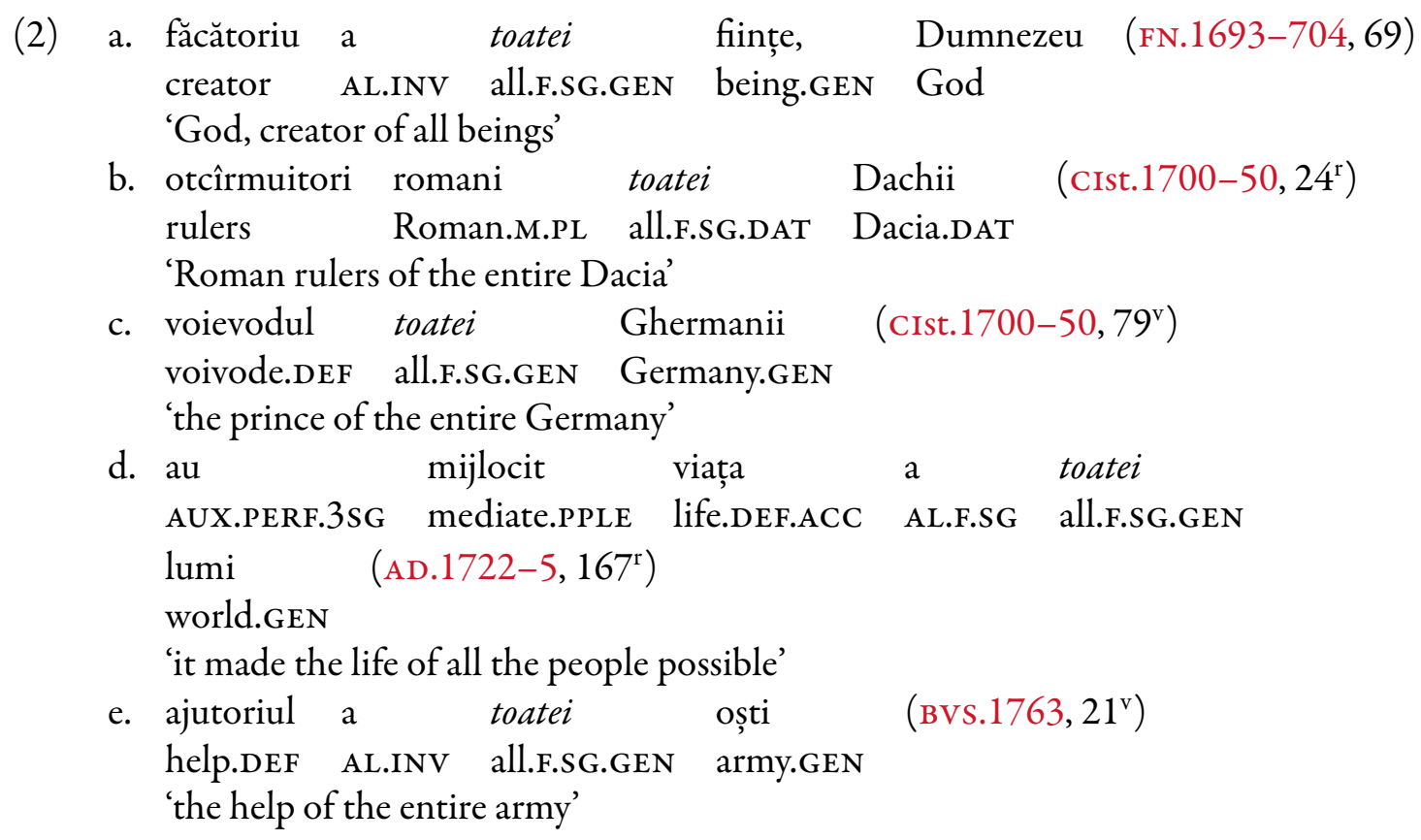

The masculine singular genitive-dative form totului is rare and is encountered in collocations like cu totului, cu totului tot, de totului tot 'completely, fully, definitively, very' $(3 a-c)^{2}$.

(3) a. Trupurile lor întregi cu totă carnea și pelița, bodies.DEF their whole.PL with all.F.SG flesh.DEF.ACC and skin.DEF.ACC cum ar hi de vro lună adormiți și zvîntați, how AUX.COND.3SG be.INF since about month dead.PL and dry.PL palmele, unghile, urechile, nasul, cu totului palms.DEF nails.DEF ears.DEF nose.DEF with all.M.SG.GEN întregi, neprăbușiți (DVs.1682-6, 487v) whole.PL NEG-break.down.PPLE.M.PL

'Their whole bodies, with all their flesh and skin, as if they had been dead and dry for about a month, palms, nails, ears, nose, all of them complete, not broken down'

\footnotetext{
${ }^{1}$ The adjectival form toatei is very rarely attested as late as the $19^{\text {th }}$ century (Croitor, 2015, p. 149).

${ }^{2}$ Collocations like $c u$ totului, cu/în totului tot are rarely attested as late as the $19^{\text {th }}$ century (Croitor, 2015, p. 149-150).
} 
b. Iar altă oaste, cîtă au Șfedul and other army how.many AUX.PERF.3sg have.PPLE Swede.DEF.NOM

in Țara Căzăcească, doo obuzuri, cu totul au

in land.Def Cossack two shells with all.M.SG AUX.PERF.3PL

luat-o moscalii, $\quad \mathrm{cu}$ ghenărari,

take.PPLE $=$ CL.ACC.F.3SG Russians.DEF.NOM with generals

$\mathrm{cu}$ ofițeri, $\mathrm{cu}$ cară, $\mathrm{cu}$ pușci, $c u$ totului tot

with officers with carts with guns with all.M.SG.GEN all

şi cu multă avere $\quad($ NL $1750-66,187)$

and with many wealth

'And another army, as many men as the Swede had in the land of the Cossacks, two bomb shells, was all captured by the Russians, including generals, officers, carts, guns, everything and many belongings'

c. Împărțirea căsaşilor cînd să va

separation.DEF.NOM spouses.GEN when CL.REFL.ACC.3SG AUX.FUT.3sG

face pentru aceaste vini (...) să

do.INF for these.F.PL faults.ACC CL.REFL.ACC.3SG

înțeleage să fie pănă la o vreame,

understand.IND.PRES.3SG S $\breve{A}_{\text {SUBJ }}$ be.SUBJ.3SG until at a time

iară nu de totului tot (Prav.1646,115)

and not of all.M.SG.GEN all

'The separation of the spouses when it is done for these faults (...) it is understood that it should be only for a period of time, not forever'

The analytic marking of the singular genitive-dative in NPs featuring the quantifier tot in anteposition is more frequent - and is attested in the earliest texts. In these contexts, the following case markers occur: the preposition $a$ (most often) $(4 \mathrm{a}-\mathrm{g})$ and $l a$ for the genitive and the dative $(4 \mathrm{~h}-\mathrm{i})$, and $d e$ for the genitive (4j); tot has a nominative-accusative form. In many texts, such as PH.1500-10, Dî, CC ${ }^{1} .1567$, MC.1620, ŞT.1644, SVI 1670, the feminine singular genitive-dative of tot is marked exclusively analytically. In other texts, the form toatei is either numerically inferior to the prepositional realization of the genitive-dative case (for example, in BVs.1763, toatei has $27,59 \%$ of the total of attestations and $a /$ la/de toată, $72,41 \%$ ), or absent, or, on the contrary, the only variant used (in CDicț.1691-7, only the prepositional construction occurs, not also toatei; however, in FN.1693-704, toatei has eight occurrences, while the prepositional construction is absent, and in CIst.1700-50, toatei has two occurrences and the prepositional construction has no attestations).
(4)
a. peirea
a toată
creștinătatea
(Dî.1600, XXXIII)
disappearance.DEF A.GEN all.F.sG Christianity.DEF
'the disappearance of all Christianity'
b. împărat a tot pămîntul (PH.1500-10,40 r)
emperor A.GEN all.M.SG earth.DEF
'emperor of all the world'
c. Dat-au
hrană a toată pelița
give.PPLE=AUX.PERF.3sG food A.DAT all.F.SG people.DEF
'He fed all the people'
d. împăratul a totu iaste Tatăl nostru
emperor.DEF A.GEN all.M.SG is Father.DEF.NOM our
den ceriu $\quad\left(\mathrm{CS}_{\mathrm{XV}} \cdot 1619,122^{\mathrm{r}}\right)$
from heaven.ACC
'the master of all is our heavenly Father'



e. naintea a toată curtea (MC.1620, 44 $4^{\mathrm{v}}$ )
in.front.of A.GEN all.F.SG court.DEF
'in front of all the court'
f. nește începături a tot rrăul (SVI 1670, 257 $\left.7^{\mathrm{r}}\right)$
some beginnings A.GEN all.M.SG evil.DEF
'the beginning of everything bad'
g. veni-va Hristos, Dumnezeul nostru, să
come.INF=AUX.FUT.3SG Christ.NOM God.DEF our SĂ $\breve{\text { SUBJ }}$
judece a toată lumea $\quad\left(\operatorname{svi} \sim 1670,60^{\mathrm{v}}\right)$
judge.SUBJ.3sG A.DAT all.F.SG people.DEF
'Christ, our Lord, will come, to judge everyone'

h. au dat poroncă la toată

AUX.PERF.3SG give.PPLE order.ACC LA.DAT all.F.SG

boierimea $\quad(\mathrm{NL} \sim 1750-66,386)$

nobility.DEF

'he ordered to all the boyars'

i. toate le-au împărțit la toată

all.F.PL CL.ACC.3PL=AUX.PERF.3SG share.PPLE LA.DAT all.F.SG

oastea (BVs.1763, 140 $)$

army.DEF

'he divided everything among the entire army'

j. asupra de tot copaciul (DPar.1683, II $\left./ 8^{\mathrm{r}}\right)^{3}$

above DE.GEN all.M.SG tree.DEF

'above the whole tree'

As far as the plural genitive-dative is concerned, in old Romanian, just like in modern Romanian, the synthetic (pronominal or adjectival) form is used, with the ending -or $(5 \mathrm{a}-\mathrm{c})$.
(5)
a. desupra tuturora (Dî.1600, XXXII) above all.PL.GEN 'above all'
b. Faraon dzise tuturor eghipteanilor
'Pharaoh said to all the Egyptians'
Pharaoh say.Ps.3sg all.PL.DAT Egyptians.DEF.DAT
(Po.1582, 145)
c. să facă voia tuturor dracilor
$\breve{S A}_{\text {SUBJ }}$ do.SUBJ.3SG will.DEF.ACC all.PL.GEN devils.DEF.GEN
'to do as all the devils' wish'

The synthetic plural genitive-dative form (just like the singular genitive-dative form) is in competition with the construction with the preposition $a(6 a-d)$, or, more rarely, la (6e) or de (for the genitive) (6f), followed by tot (and the noun) in the nominative-accusative.
(6) a. rădăcina a toate bunătățile iaste root.DEF.NOM A.GEN all.F.PL good.things.DEF is
dragostea $\left(\mathrm{CC}^{2} .1581,47\right)$
love.DEF
'the root of all the goodness is love'

\footnotetext{
${ }^{3}$ In the structure with the genitive marker $d e$, the preposition is followed by a noun phrase with a definite determiner. This type of structure has disappeared.
} 


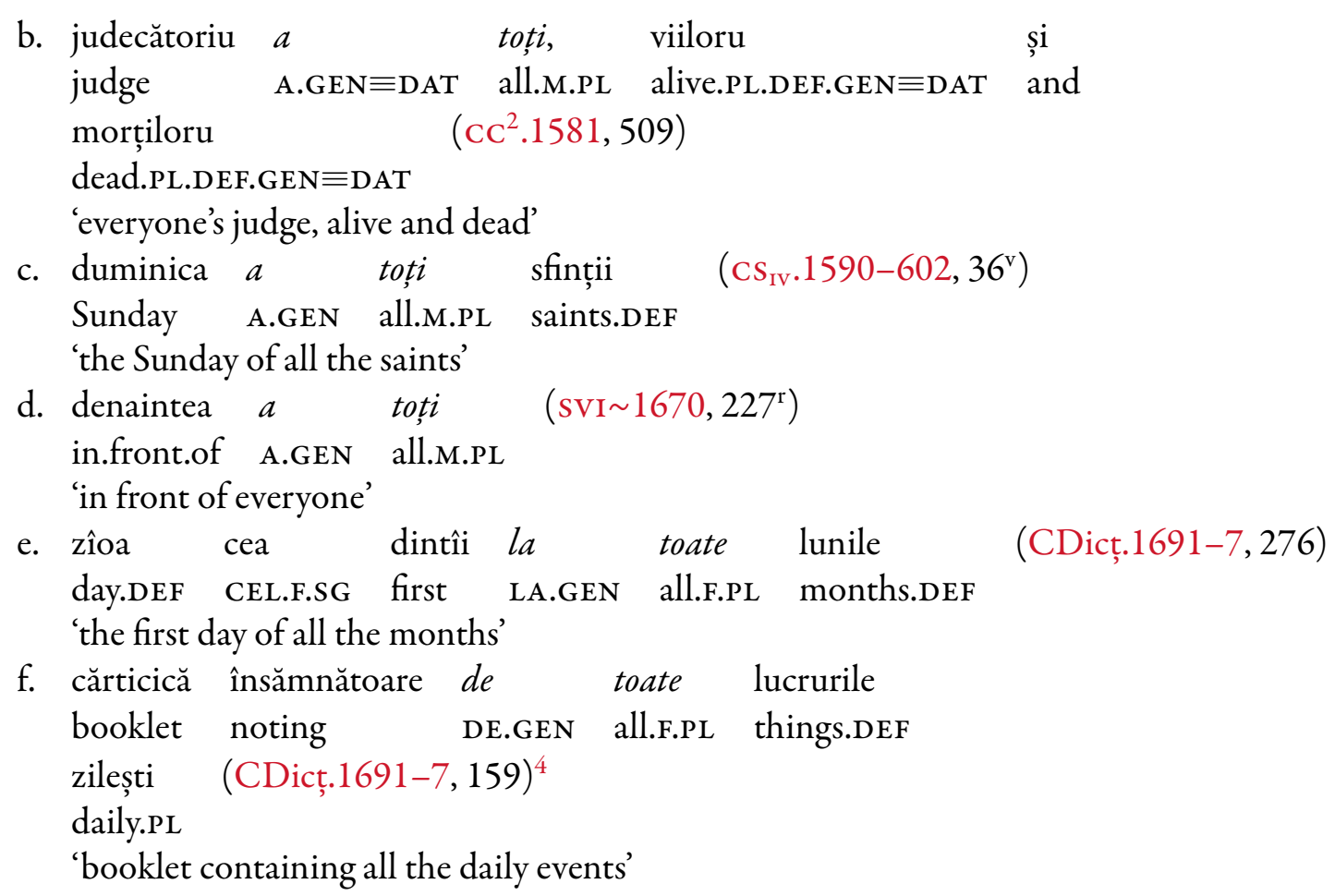

The plural genitive-dative pronominal form includes, though not obligatorily, the final particle $-a$, like in the modern language [compare $(7 \mathrm{a}-\mathrm{b})$ with $(8 \mathrm{a}-\mathrm{d})]$. In many texts, the pronominal forms with and without final - $a$ coexist (Dî, CC ${ }^{1} .1567$, MC.1620, svi 1670, DPar.1683, CLM.1700-50, BVs.1763); more rarely, a single form is used (for example, in PH.1500-10, șT.1644, and Prav.1780, only tuturor occurs, used as a pronoun and as an adjective).

(7) a. da tuturora den dăstul toate $\left(\right.$ svi 1670, 262 $\left.{ }^{\mathrm{r}}\right)$ give.IMPERF.3SG all.PL.DAT of enough all.F.PL 'he gave everyone everything in abundance'

b. Tuturora această mustrare făcea (CLM.1700-50,177²) all.PL.DAT this reprimand.ACC make.IMPERF.3sG 'He reproached this to all of them'

(8) a. fața tuturor unul cătră alalt să face.DEF all.PL.GEN one.DEF to other $\breve{S}_{\text {SUBJ }}$ stea (Po.1582, 262)

stay.SUBJ.3SG 'they should all face one another'

b. Facem de scire tuturoru (Dî.1593, CXIII) make.IND.PRES.1PL of know all.PL.DAT

'We let everyone know'

c. ziditoriul tuturor (șT.1644,203) creator.DEF all.PL.GEN 'the creator of all (things)'

d. Însă nu era cu știrea tuturor pentru but not be.IMPERF.3Sg with knowledge.DEF.ACC all.PL.GeN for Dabijea vodă (CLM.1700-50,318 $)$

Dabijea voivode 'But not everyone knew about prince Dabijea'

\footnotetext{
${ }^{4}$ As far as example (6f) is concerned, which is attested by Pană Dindelegan (2013, p. 168), the author shows that the nominal phrase in the genitive has the feature [+ Definite], and de is selected by postverbal adjective derived with - tor.
} 
However, the plural genitive-dative adjectival form has a different behaviour than in modern Romanian (which does not accept the final particle - a: *tuturora copiilor 'of/to all the children'). In old Romanian texts, it is attested without $-a(9 a-b)$, as well as with $-a(10 a-d)$. In some texts in the corpus, only the adjectival tuturor occurs (Dî, PH.1500-10, MC.1620, șT.1644, DPar.1683, Prav.1780), and in others, tuturor, as well as tuturora, are attested as adjectives (CC ${ }^{1} .1567$, PO.1582, NT.1648, sVI 1670, BVs.1763).
(9) a. înaintea tuturor oamenilor $\quad\left(\mathrm{CC}^{1} .1567,128^{\mathrm{r}}\right)$
in.front.of all.PL.GEN people.PL.GEN
'in front of all the people'
b. izvorul a tuturor răutăţilor (CLM.1700-50,239 $)$
source AL.INV all.PL.GEN evil.PL.GEN
'the source of all evil'
(10) a. au porîncit apostolilor și tuturora
AUX.PERF.3SG order.PPLE apostles.DAT and all.PL.DAT
popilor $\quad\left(\right.$ CM.1567, 255 $\left.5^{\mathrm{r}}\right)$
priests.DAT
'he ordered to the apostles and to all the priests'
b. făcea bucurie mare tuturora fraților (NT.1648, 154v)
make.IMPERF.3PL joy great all.PL.DAT brothers.DAT
'they caused great joy to all the brothers'
c. Știi cîte făcuiu celora ce se
know.IND.PRES.2sG how.many make.PS.1sG those.DAT that CL.REFL.ACC.3PL
chema călugări și tuturora creștinilor? (svi 1670, 19ª)
call.IMPERF.3PL monks and all.PL.DAT Christians.DAT
'Do you know how much I did for the ones called monks and for all the Christians?'
d. imperator al tuturora părților lumii $\left(\right.$ BVs.1763, 107 ${ }^{\mathrm{r}}$ )
emperor AL.M.SG all.PL.GEN parts.GEN world.GEN
'emperor of all the parts of the world'

In modern Romanian, the particle $-a$ marks the absence of the noun with a definite determiner and distinguishes the indefinite plural genitive-dative pronoun tot from the indefinite adjective. The reference of the empty nominal head implied by the pronoun tuturora can be retrieved, both in modern and old Romanian, by its relation with an antecedent (11a) or, when it is not in relation with an antecedent, it receives a generic interpretation (11b) (see Giurgea, 2010, p. 169-171 for the analysis of the empty nominal head as pro- $N$ and for its possible readings).

a. împle sacii acestor oameni $\mathrm{i}_{\mathrm{i}} \mathrm{cu}$ grîu, atîta fill.IMP.2sG sacks.DEF.ACC these.M.GEN people with wheat so.much cît vor putea duce și banii tuturora $\left[\varnothing_{\mathrm{i}}\right]$ as AUX.FUT.3PL can.INF carry.INF and money.DEF.ACC all.PL.GEN pune desupra în sacii lor (Po.1582, 155) put.IMP.2sG above in sacks.DEF.ACC their 'fill the sacks of these people with grain, as much as they can carry and put everyone's money in the sacks on top of the grain'

b. Soarele dereptu iaste Dumnezeu, cumu iaste scrisu sun.DEF.NOM right is God.NOM how is write.PPLE că tuturora $[\varnothing]$ întru un chipu luminează that all.PL.DAT in a manner light.IND.PRES.3SG lucirea dulceției sale $\left(\mathrm{CC}^{2} .1581,439\right)$ shine.DEF.NOM sweetness.GEN his.POSS 
'God is the true sun, as it is written that the glitter of his sweetness shines to everyone in the same way'

The structures containing an adjectival form with the particle $-a$ and a noun with a definite determiner show that, in old Romanian, the occurrence of the final particle - $a$ does not necessarily imply the ellipsis of $N$ (a pro- $N)$. Also, in other old Romanian structures, such as the ones with the indefinite fiecare 'each' (12a) or with the relative care 'which' (12b), the adjectival genitive-dative form can take the final - $a$ (just like the pronominal form), differently from modern Romanian.

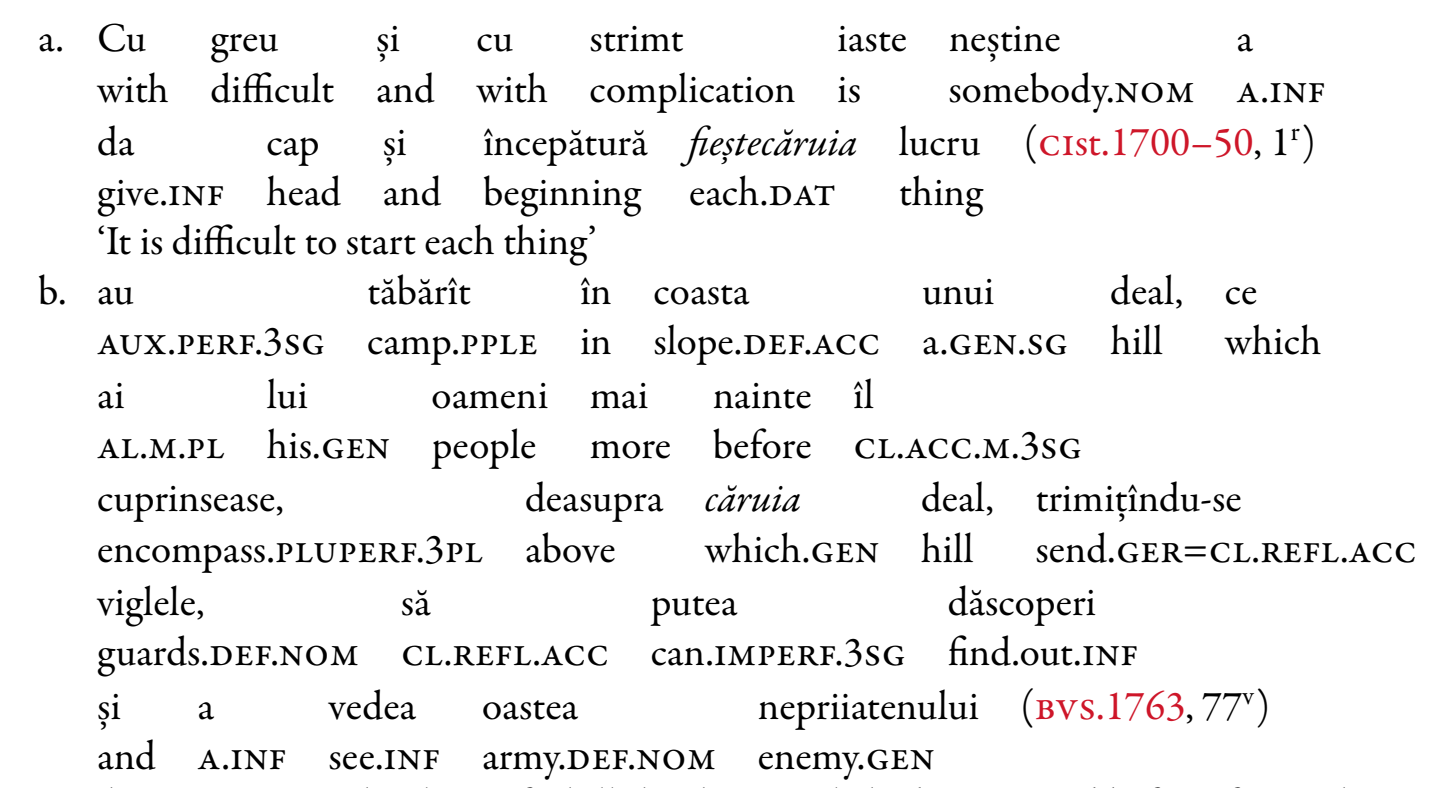

'he set camp on the slope of a hill that his people had conquered before, from whose top, sending his guards, he could spot and see the army of his enemy'

When tot is the first element of the nominal phrase, the singular and plural genitive-dative marking can also be mixed, with the preposition $a$ and the genitive-dative inflection attached to the nominal stem $(13 \mathrm{a}-\mathrm{g})^{5}$. In such structures, that have been eliminated, case is expressed redundantly, on both elements of the nominal phrase. The double expression of case is possible in old Romanian in other structures as well, such as those in which the article marks case on more elements of the phrase (14) (Stan, 2016a, p. 291-292).
a. Și-1
puse
and $=$ CL.ACC.M.3sG put.PS.3sG
domnu
master
\begin{tabular}{lll} 
caseei & sale & \multicolumn{1}{c}{ şi } \\
house.DEF.DAT & his.POSS & and \\
sale & $\left(\right.$ PH.1500-10, $\left.88^{\mathrm{v}}\right)$
\end{tabular}
giudețu a toată agonisiteei
his.poss
judge A.DAT all.F.SG fortune.DEF.DAT his.POss
'And he appointed him head of his house and master of all his wealth'
b. gice a toți creștinilor $\left(\mathrm{CC}^{1} .1567,6^{\mathrm{V}}\right)$
says A.DAT all.M.PL Christians.DEF.DAT
'he says to all the Christians'
c. muma a toți viilor
mother.DEF A.GEN all.M.PL alive.PL.DEF.GEN
'mother of all those living'
d. Şi dziseră Moisi și Aron a toți filor and say.Ps.3PL Moses and Aaron A.DAT all.M.PL sons.Def.DAT
lu Israil (Po.1582, 231)
LUI.GEN Israel

\footnotetext{
${ }^{5}$ This type of marking has traces in the $19^{\text {th }}$ century (Pană Dindelegan, 2013, p. 169; Nedelcu, 2015, p. 56).
} 
'And Moses and Aaron said to all the sons of Israel'

e. sîntem slugi credincioase a toată

be.IND.PRES.1PL servants.F faithful.F.PL A.DAT all.F.SG

creștinătăței (Dî.1600, XLIV)

Christianity.DEF.DAT

'we are faithful servants of all of Christianity'

f. innaintea a tot săborului (AD.1722-5, 127 $\left.7^{\mathrm{v}}\right)$

before A.GEN all.M.sG synod.DEF.GEN

'before the whole synod'

g. cu multă păreare rea a tot

with much.F.sG opinion bad.F.SG A.GEN all.M.SG

norodului creștinescu (BVs.1763,102 ${ }^{\mathrm{v}}$ )

people.DEF.GEN Christian

'with much regret of all the Christian people'

(14) cinstitului și preaosfinţitului părintelui

honoured.M.SG.DEF.DAT and most.sacred.M.SG.DEF.DAT father.DEF.DAT

nostru arhiepiscop (DRH,B.1653, 14, apud Stan, 2016a, p. 291)

our archbishop

'to our honoured and most sacred archbishop'

\section{Syntactic characteristics of the indefinite tot}

As far as the syntactic behaviour of the indefinite tot is concerned, there is to note both similarities with the modern language and oscillations and distinctive features of old Romanian.

\subsection{The word order of the indefinite tot}

Just like in modern Romanian, the indefinite tot can occur both anteposed (15a), and postposed to the nominal phrase $(15 \mathrm{~b}-\mathrm{c})$ (for the possibility of movement of the quantifier tot, analysed as 'floating' or 'external', see Stan, 2015, p. 599; Nicolae, 2016, p. 152).
a. toate slugile lui $\left(\mathrm{CS}_{\mathrm{XI}} \cdot 1583-619,94^{\mathrm{r}}\right)$
all.F.PL servants.DEF his.GEN 'all his servants'
b. chemă slugile call.PS.3sG servants.DEF.ACC his.GEN all.F.PL 'he called all his servants'
c. sfinții toți $\left(\mathrm{CS}_{\mathrm{IV}} \cdot 1590-602,36^{\mathrm{v}}\right)$
saints.DEF all.M.PL
'all the saints'

In old Romanian, the word order of tot is more permissive, as the quantifier can move to positions that it does not accept any longer, as in examples $(16 \mathrm{a}-\mathrm{e})$, where tot is anteposed (16a-d) or postposed to pronouns (16e). In this type of structure, the word order encountered is more frequently similar to that of modern Romanian (17a-c).
a. toți voi (CL.1570, 34 $4^{\mathrm{v}}$, apud Stan, 2016b, p. 352)
all.M.PL you.PL
'all of you'

\footnotetext{
${ }^{6}$ In modern Romanian, similar structures are attested: rudele lui toate 'all his relatives' (internet).
} 
b. Toți voi vă veți sminti în

all.M.PL you.PL CL.REFL.ACC.2PL AUX.FUT.2PL trouble.INF in

Mine în ceastă noapte (NT.1648, 35 $\left.{ }^{\mathrm{r}}\right)$

me.ACC in this.F.sG night.ACC

'You will all deny me tonight'

c. căzu frică spre toți ei $\quad\left(\mathrm{NT} .1648,160^{\mathrm{v}}\right)$

fall.ps.3sg fear.NOM on all.M.PL them

'fear fell on all of them'

d. Pentru cari toate aceaste pricini tuturor dumneavoastră

for which all.F.PL these.F.PL causes all.PL.DAT you.POL

trebuie a fi cunoscut (BVs.1763,15 ${ }^{\mathrm{v}}$ )

must A.INF be.INF know.PPLE

'For which all these causes must be known to all of you'

e. În acest chip fu dat lui Avraam ocină

in this way be.Ps.3sg give.PPLE LUI.DAT Abraham property

lui pămîntul lui Efron (...) pre vedearea feciorilor

his land.DEF.nOM LUI.GEN Ephron for sight.DEF.ACC sons.GeN

lui Het și acelora tuturora, carii intra și

LUI.GEN Het and those.gen all.PL.GEN who enter.IMPERf.3PL and

eșiia pre poarta oraşului lor (Po.1582,74)

exit.IMPERF.3PL through gate.DEF.ACC town.GEN their.GEN

'This way Ephron's land was given to Abraham to own (...) in the sight of the sons of Het and all of those that went through the gate of their town'

(17) a. Împreună întru alu mieu liubovu împreunai pre voi, cumu together in AL.M my love.ACC unite.Ps.1SG DOM you.PL how

iaste şi urîciunea împreună spre voi toți $\left(\mathrm{CC}^{2} .1581,470\right)$ is also hate.DEF.NOM unite.Ps.3sg DOM you.PL all.M.PL

'I have made all of you come together in my love the same as hate made all of you come together'

b. $e i$ toți giudecară pre El a fi

they all.M.PL judge.PS.3PL DOM Him A.INF be.INF

vinovat morției $\left(\mathrm{NT} .1648,61^{\mathrm{v}}\right)$

guilty death.DAT

'they all judged Him to be guilty of death'

c. zise Iacov caseei și tuturor

say.PS.3sG Jacob.NOM house.DAT his.POSs and all.PL.DAT

acelora carii era cu el (Po.1582, 119)

those.DAT who be.IMPERF.3PL with him

'Jacob said to his family and to all those that were with him'

An explanation for the different word order of tot in relation to certain pronouns as compared to modern Romanian can be the influence of the original text (for instance, as Stan, 2016b, p. 352 shows referring to example (16a), the position of the quantifier tot can be analysed as copying the word order of Slavonic).

Tot has lost its ability to occur after the alternative form alt, both in a nominal phrase with an overt head noun (18a), and in one with nominal ellipsis $(18 \mathrm{~b}-\mathrm{c})$. In modern Romanian, only phrases with toate and the indefinite alte taking a so-called 'definite article' are possible (toate altele) ${ }^{7}$.

${ }^{7}$ Analysing the period between 1521-1640, Frâncu (2009, p. 69) considers that one of its characteristics is the frequent use of the 'undetermined' forms of the pronoun alt. 
(18)

$$
\text { amîndoi au }
$$

cădzut la robiie, commanders.DEF.NOM both AUX.PERF.3PL fall.PPLE at captivity.ACC

Sinavschii și alte toate capete (CLM.1700-50,246 ${ }^{\mathrm{r}}$ )

Sinavschii and other all.F.PL heads

'Both commanders became prisoners, Sinavschii and all the other leaders'

b. alte toate va tocmi Dumnezeu (Dî.1593, XCIII)

other all.F.PL.ACC AUX.FUT.3sg establish.INF God.NOM

'God will decide all the others'

c. Ceteaște și alte toate $\left(\mathrm{CC}^{1} .1567,182^{\mathrm{v}}\right)$

read.IMP.2sG also other all.F.PL.ACC

'Read also all the other (writings)'

\subsection{Determination/non-determination of the noun in structures with tot}

Just like in modern Romanian, in old Romanian, the quantifier tot selects a noun-singular or pluralwith a definite determiner, that is with an enclitic definite article $(19 a-b)$ or with another definite determiner $(19 \mathrm{c}-\mathrm{e})$. This condition is not systematically obeyed in old Romanian, as tot can also select an undetermined noun $(20 \mathrm{a}-\mathrm{p})$.
a. totu omulu
e ca iarba
$\left(\mathrm{CC}^{2} .1581,221\right)$
all.M.sG man.DEF.NOM is like grass.F.SG.DEF
'all people are like grass'

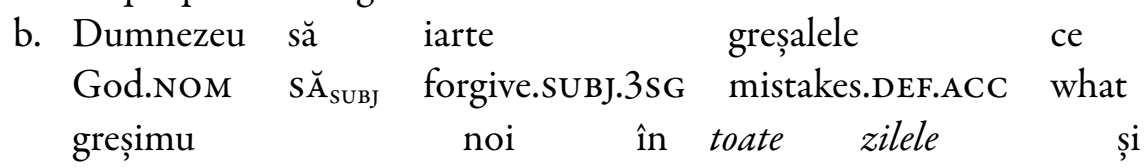
mistake.IND.PRES.1PL we.NOM in all.F.PL days.DEF.ACC and
in toate ceasurile $\left(\mathrm{CC}^{2} .1581,47\right)$
in all.F.PL hours.DEF.ACC
'God forgive the sins we commit every day and every hour'
c. toți cei oameni $\left(\mathrm{CC}^{1} .1567,146^{\mathrm{v}}\right)^{8}$
all.M.PL CEL.M.PL people
'all those people'

d. semînțeei tale voiu $\mathrm{da}$ toate

seed.F.SG.DEF.DAT your AUX.FUT.1sG give.INF all.F.PL

aceaste tinuture (PO.1582,85)

these.F.ACC lands.ACC

'I shall give these lands to your people'

e. toț alalți boiari (Dî.1599, XVIII)

all.M.PL others boyars

'all the other boyars'

(20)
a. spăl
în toate nopți
aşternutulu
wash.IND.PREs.1sG in all.F.PL nights bed-clothes.DEF.ACC
mieu (PH.1500-10, $\left.4^{\mathrm{r}}\right)$
my
'I wash my bed linen every night'
b. cu toată usîrdie numai ale lu Dumnezeu with all.F.SG diligence.ACC only AL.F.PL LUI.GEN God

\footnotetext{
${ }^{8}$ The direct association of the demonstrative article $c e l$ with the noun is no longer possible in the modern language (but a structure like toți cei trei oameni 'all the three men' is possible).
} 


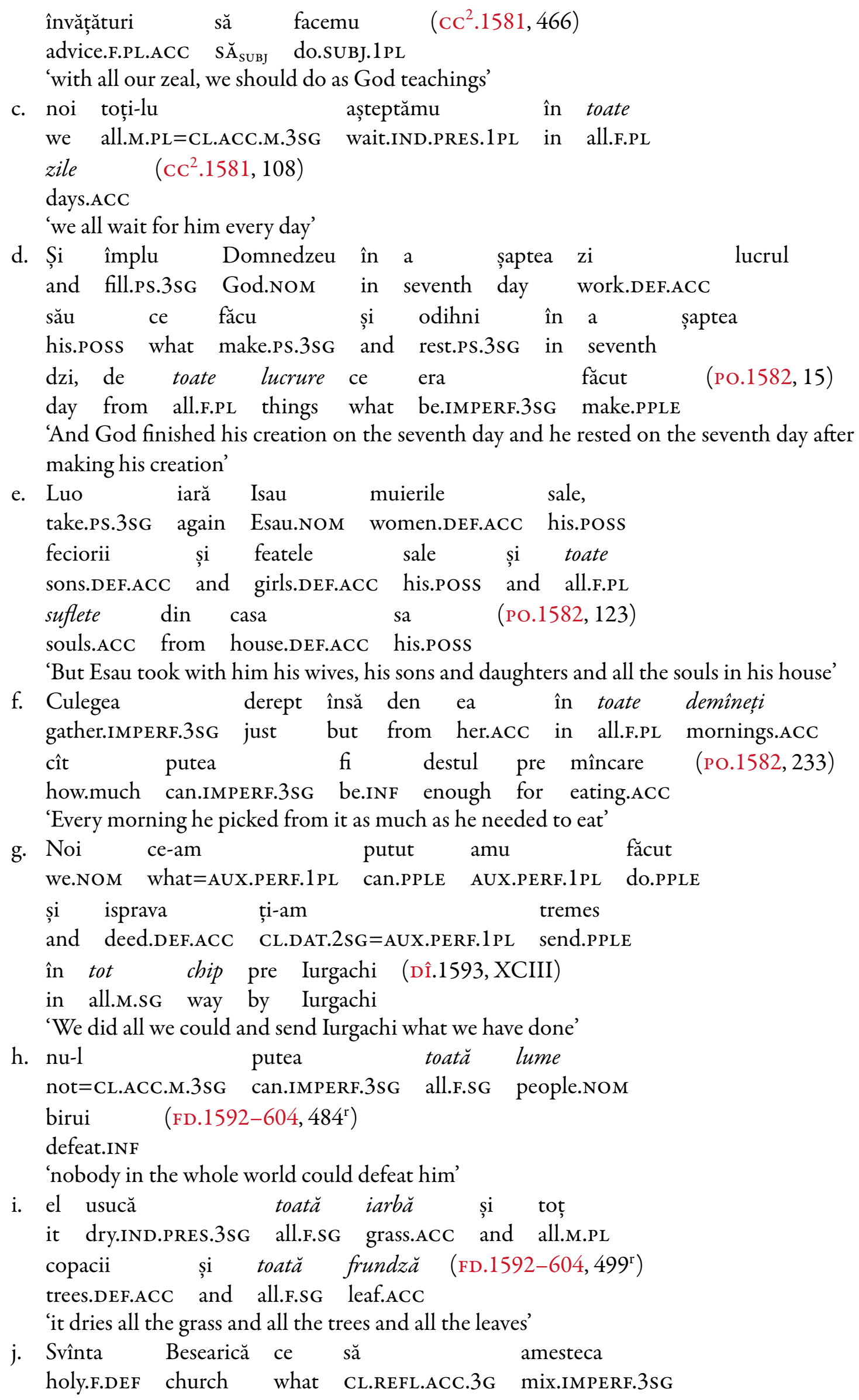


în toată vreamea și în toate dzile

in all.F.SG time.DEF.ACC and in all.F.PL days.ACC

(șT.1644, 238-239)

'the Holy Church that interfered all the time, every day'

k. Spăla-voiu in toate nopți patul

wash.INF $=$ AUX.FUT.1sG in all.F.PL nights.ACC bed.DEF.ACC

mieu $\quad\left(\right.$ svi $\left.\sim 1670,96^{\mathrm{r}}\right)$

my

'I shall wash my bed every night'

1. acolea de față 〈este> mărturie toată oaste

there present is witness all.F.SG army.NOM

îngerească $\quad\left(\right.$ svi 1670, 181 $\left.{ }^{\mathrm{r}}\right)$

angelic.F.SG

'the whole army of angels is present there as a witness'

m. Cade-să tine în toate vremi

ought.IND.PRES.3SG=CL.REFL.IMPERS yOu.ACC in all.F.PL times

a cînta în toate glasuri cuvioase,

$\mathrm{A}_{\mathrm{INF}}$ sing.INF in all.F.PL voices.ACC pious

Fiiule a lui Dumnădzău (DPar.1683, IV/9 ${ }^{\mathrm{r}}$ )

son.voc AL.INV LUI.GEN God

'Son of God, we ought to sing with devout voices all the time'

n. au trimis soli pe la toate

AUX.PERF.3SG send.PPLE messengers.ACC at all.F.PL

țări creștine (CLM.1700-50, 191 ${ }^{\mathrm{r}}$ )

countries.ACC Christian.F.PL

'he sent messengers to all the Christian countries'

o. îmbla în tot cias, cum să

walk.IMPERF.3PL in all.M.SG hour.ACC how CL.REFL.IMPERS

dzice, cu dzilele a mînă (CLM.1700-50, 176 ${ }^{\mathrm{r}}$ )

says with days.DEF.ACC at hand.ACC

'they were living dangerously all the time, as they say'

p. N-au lipsitu nemică den toate

not=AUX.PERF.3sG lack.PPLE nothing of all.F.PL

podoabe (CLM.1700-50,237 )

jewels.ACC

'None of all his jewelery was missing'

In structures containing an adjective preposed to the noun (21a-b), we also notice oscillations in determination, compared to modern Romanian, where the adjective is obligatorily determined [as in (21a)].

a. toate blagosloveștile glasuri (Svi 1670,163 $\left.{ }^{\mathrm{r}}\right)$

all.F.PL blessed.PL.DEF.ACC voices

'all the blessed voices'

b. Toată trupească mîngîiare șî răpaos,

all.F.SG bodily caress.ACC and restfulness.ACC

pănă în sfîrșit o arunca $\quad\left(\right.$ SVI 1670, 102 $\left.{ }^{\mathrm{r}}\right)$

until in end CL.ACC.F.3SG throw.IMPERF.3PL

'They refused all the bodily comfort and rest till the end'

Oscillations in articulation also occur when the structure includes a numeric quantifier (22a-b), a context in which modern Romanian has only preserved the possibility for a determined noun to be preceded by the quantifier [as in (22a)]. 


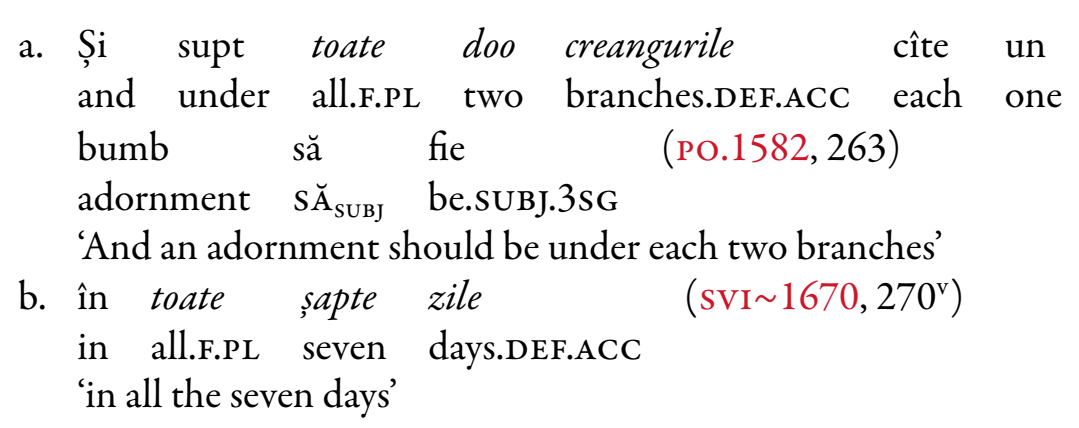

As shown in examples (20a-p), (22b), the non-determination of the noun that is postposed to tot is attested both in original and in translated texts. In order to explain the undetermined forms in the construction with $t o t$, more frequent in the $16^{\text {th }}$ century, the influence of foreign models must be considered (see Stan, 2015, p. 600 and the bibliography therein). For example, the absence of the article in Slavonic is relevant for a series of texts in which the noun accompanied by tot does not take the article.

The typological and diachronic analysis of the distribution of the quantifier tot in relation to the definite determiner made by $S \tan (2015)$ shows that Romanian has eliminated the pattern $t o t+$ undetermined noun, attested in other old Romance idioms as well.

The undetermined nominal structures in old Romanian can be referential-occupying argumental positions or occuring as complements of prepositions ${ }^{9}$ - , as well as non-referential (see Stan, 2015, p. 600 for the referential and non-referential reading of structures with tot + undetermined noun). The (non-) determination of the noun in structures with tot does not depend on the distinction generic (23a) vs. non-generic (referential) (23b).
a. In toate dzile
in all.F.PL days
miluiaște
și împrumut
take.pity.IND.PRES.3SG
and loan.ACC
dă dereptul
și săm<ì $<$ ța
lui
give.IND.PRES.3SG
righteous.DEF.NOM
and seed.DEF.NOM
his.GEN
în blagoslovenie va
fi $\quad($ PH.1500-10,32 $)$
in blessing.ACC AUX.FUT.3sG be.INF
'He takes mercy and gives loans every day, so that his offspring will live in bless'
b. Fură lacrămile meale mie pînre dzua și noaptea
be.PS.3PL tears.DEF.NOM my.F me.DAT bread day.DEF and night.DEF
cîndu grăiia mie în toate dzile (PH.1500-10,35 $5^{\mathrm{v}}$
when tell.IMPERF.3sg me.DAT in all.F.PL days.ACC
'I cried day and night when he talked to me every day'

\section{Conclusions}

The morphosyntactic characteristics mentioned in this article-illustrated both by original and translated texts - stand as evidence for the great variation in the behaviour of the indefinite tot in old Romanian, which has steadily decreased up to modern Romanian, being preserved in some contexts and being eliminated in other situations.

At the morphological level, the variation regards, on the one hand, the types of oblique case marking for the singular, which are at the same time synthetic, analytic and mixed (toatei + genitive-dative noun,

\footnotetext{
${ }^{9} \mathrm{~A}$ comparison of examples (20o) and (20p) shows that, although the nominal complement of the quantifier is undetermined (cias 'hour', podoabe 'jewelry'), their reading is different: in (20o) it is non-referential, while in (20p) is referential. In Romanian, the absence of the article after prepositions can be corellated with the definite reading of the noun (Nedelcu, 2013, p. 459-461).
} 
Isabela Nedelcu

a/la/de toat $\breve{a}+$ nominative-accusative noun, a toat $\breve{a}+$ noun in the genitive-dative) and for the plural (tuturor(a), a/la/de toți/toate + noun with a nominative-accusative form, a toți/toate + noun in the genitivedative), and, on the other hand, the inconsistent occurrence of the final particle $-a$ in the structure of the plural genitive-dative form. In modern Romanian, the variation in the genitive-dative marking is limited to the plural forms tuturor (a) all.PL.GEN $\equiv$ DAT vs. a/la toți/toate A/LA all.M.PL/all.F.PL, and the formal variation \pm particle $-a$ is only preserved in the case of the pronoun (the adjective excludes the particle $-a$ ).

Syntactically, it is important to note the greater word order variation of tot, which is also encountered in combinations which have a fixed word order in the present-day language (for example, tot + personal pronoun, the alternative form alt 'other' + tot $)$, and the variation of tot-constructions with respect to the articulation of the accompanying noun. The quantifier tot has lost a series of syntactic characteristics specific to the old language, among which the most important one is the capacity to select an undetermined noun.

\section{Bibliography}

\section{A. Corpus}

AD.1722-5 = Antim Ivireanul, Didahii, in Opere, ed. G. Ștrempel, Editura Minerva, București, 1972.

Bvs.1763 = Vlad Boțulescu de Mălăiești, Scrieri, I. Viața lui Scanderbeg, ed. E. Timotin \& O. Olar, Editura Univers Enciclopedic Gold, București, 2013.

CazV.1643 = Varlaam, Cazania, ed. J. Byck, Fundația Regală pentru Literatură și Artă, București, 1943.

$\mathrm{CC}^{1} .1567=$ Coresi, Tûlcul evangheliilor, in Tîlcul evangheliilor și molitvenic românesc, ed. V. Drimba, Editura Academiei, București, 1998.

$\mathrm{CC}^{2} .1581$ = Coresi, Evanghelie cu invvățătură, in Carte cu invvățătură (1581), vol. I, Textul, ed. S. Pușcariu \& Al. Procopovici, Atelierele Grafice Socec, București, 1914.

CDicț.1691-7 = Teodor Corbea, Dictiones latina cum valachica interpretatione, ed. A.-M. Gherman, Editura Clusium, ClujNapoca, 2001.

CIst.1700-50 = Constantin Cantacuzino, Istoriia Țărîi Rumânești, in Istoria Țărîi Rumânești atribuită stolnicului Constantin Cantacuzino, ed. O. Dragomir, Editura Academiei Române, București, 2006.

CL.1570 = Coresi, Liturghier, ed. Al. Mareș, Editura Academiei RSR, București, 1969.

CLM.1700-50 = Miron Costin, Letopisețul Țărîi Moldovei, in Opere, ed. P.P. Panaitescu, Editura de Stat pentru Literatură și Artă, București, 1958.

CM.1567 = Coresi, Molitvenic, in Tîlcul evangheliilorși molitvenic românesc, ed. V. Drimba, Editura Academiei, București, 1998. $\mathrm{CS}_{\mathrm{IV}} \cdot 1590-602, \mathrm{Cs}_{\mathrm{XI}} \cdot 1583-619, \mathrm{Cs}_{\mathrm{Xv}} \cdot 1619$ = Codex Sturdzanus, ed. Gh. Chivu, Editura Academiei Române, București, 1993. Dî = Documente și însemnări românești din secolul al XVI-lea, text stabilit și indice de Gh. Chivu, M. Georgescu, M. Ioniță, Al.

Mareș și Al. Roman-Moraru, Editura Academiei Române, București,1979.

DPar.1683 = Dosoftei, Parimiile preste an, Iaşi, 1683, ed. M. Ungureanu, Editura Universității „Alexandru Ioan Cuza”, Iași, 2012.

DRH,B = Documenta Romanie Historica. B. Țara Românească, Editura Academiei Române, București, vol. XXXVIII (1653), 2009.

DVs.1682-6 = Dosoftei, Viața și petreacerea svinților, ed. R. Frențiu, Editura Echinox, Cluj-Napoca, 2002.

FD.1592-604 = Floarea darurilor, in Roman Moraru, Al. (ed.) (1996). Cele mai vechi cărți populare in literatura română, 1 ,

Editura Minerva, București.

FN.1693-704 = Foletul Novel. Calendarul lui Constantin Vodă Brîncoveanu (1693-1704), ed. E. Vîrtosu, Monitorul Oficial

și Imprimeriile Statului, București, 1942.

MC.1620 = Mihail Moxa, Cronograf, in Cronica universală, ed. G. Mihăilă, Editura Minerva, București, 1989.

NL 1750-66 = Ion Neculce, Letopisețul, in Ion Neculce, Letopiseţul Țării Moldovei și O samă de cuvinte, ed. I. Iordan, Editura

de Stat pentru Literatură și Artă, București, ed. a II-a, 1959.

NT.1648 = Noul Testament, Editura Reîntregirea, Alba Iulia, 1998 .

PH.1500-10 = Psaltirea Hurmuzaki, ed. I. Gheție \& M. Teodorescu, Editura Academiei Române, București, 2005.

po.1582 = Palia de la Orăștie, ed. V. Pamfil, Editura Academiei Române, București, 1968.

Prav.1646 = Carte românească de invvățătură, 1646, ed. A. Rădulescu, Editura Academiei, București, 1961.

Prav.1780 = Pravilniceasca condică, 1780, ed. A. Rădulescu, Editura Academiei, București, 1957.

svi 1670 = Varlaam și Ioasaf, in Stanciu Istrate, M. (2013). Reflexe ale medievalității europene in cultura română veche: Var-

laam și Ioasaf in cea mai veche versiune a traducerii lui Udriște Năsturel, Editura Muzeului Național al Literaturii Române,

București.

șт.1644 = Şeapte taine a besearecii, Iaşi, 1644, ed. I. Mazilu, Editura Universităţii „Alexandru Ioan Cuza”, Iaşi, 2012. 


\section{B. References}

Croitor, B. (2015). Pronumele [Secolul al XIX-lea], in Chivu, Gh., Pană Dindelegan, G., Dragomirescu, A., Nedelcu, I. \& Nicula, I. (eds), Studii de istorie a limbii române. Morfosintaxa limbii literare in secolele al XIX-lea şi al XX-lea, ediție revăzută și adăugită, Editura Academiei Române, București, p. 121-172 [1 $1^{\text {st }}$ ed.: 2012].

Frâncu, C. (2009). Gramatica limbii române vechi (1521-1780), Casa Editorială Demiurg, Iași.

Giurgea, I. (2010). Pronoms, déterminants et ellipse nominale. Une approche minimaliste, Editura Universității din București, București.

Giurgea, I. (2013). The syntax of determiners and other functional categories, in Dobrovie-Sorin, C. \& Giurgea, I. (eds), A Reference Grammar of Romanian, volume 1: The Noun Phrase, John Benjamins Publishing Company, Amsterdam / Philadelphia, p. 97-174, Crossref.

Nedelcu, I. (2013). Prepositions and Prepositional Phrases, in Pană Dindelegan, G. (ed.), The Grammar of Romanian, Oxford University Press, Oxford, p. 451-465.

Nedelcu, I. (2015). Substantivul [Secolul al XIX-lea], in Chivu, Gh., Pană Dindelegan, G., Dragomirescu, A., Nedelcu, I. \& Nicula, I. (eds), Studii de istorie a limbii române. Morfosintaxa limbii literare in secolele al XIX-lea şi al XX-lea, ediție revăzută şi adăugită, Editura Academiei Române, București, p. 37-62 [1 $1^{\text {st }}$ ed.: 2012].

Nicolae, Al. (2016). Cuantificatorul, in Pană Dindelegan, G. (ed.), Gramatica de bază a limbii române, Editura Univers Enciclopedic Gold, București, p. 374-378 [1 $1^{\text {st }}$ ed.: 2010].

Pană Dindelegan, G. (2013). Flexiunea cazuală - intre analitic și sintetic. Cardinale și cuantificatori non-numerici în româna veche, in "Limba română", vol. LXII, nr. 2, p. 159-173.

Stan, C. (2015). Proprietăți sintactice ale adjectivului tot in limba română veche, in Pomian, I. (coord.), Mocanu, N. (ed.), Înspre și dinspre Cluj. Contribuții lingvistice. Omagiu profesorului G.G. Neamțu la 70 de ani, Editura Scriptor și Editura Argonaut, Cluj-Napoca, p. 595-603.

Stan, C. (2016a). The article and other determiners, in Pană Dindelegan, G. (ed.), The Syntax of Old Romanian, Oxford University Press, Oxford, p. 288-304, Crossref.

Stan, C. (2016b). Pronominal quantifiers, in Pană Dindelegan, G. (ed.), The Syntax of Old Romanian, Oxford University Press, Oxford, p. 352-356, Crossref. 